\title{
Epidemiological characteristics and HIV-related oral lesions observed in patients from a Southern Brazilian city
}

\section{Características epidemiológicas e das lesões bucais associadas ao HIV observadas em pacientes de uma cidade sul-brasileira}

\begin{abstract}
Purpose: To assess the epidemiological characteristics and associated oral lesions of HIV adult carriers in a southern Brazilian city.

Methods: A retrospective survey was conducted to review the medical records of 534 patients treated at 5 referral health centers.

Results: Nearly $52 \%$ of the patient sample was male, $88.2 \%$ were older than 30 years of age, $58 \%$ had been diagnosed with an advanced stage of HIV disease and $78.1 \%$ presented rapid rates of HIV progression to AIDS. Harmful habits were common (31.9\%), and $35 \%$ of the patients were unemployed. Approximately $60 \%$ of the subjects used highly active antiretroviral therapy. Tuberculosis was the most commonly observed systemic illness (18.5\%), and oral candidiasis was the most prevalent lesion in the oral cavity (50\%). A higher risk for tuberculosis onset was associated to illicit drugs use and oral candidiasis and hairy leukoplakia.

Conclusion: The high prevalence of concurrent diseases and the rapid progression to AIDS highlight the need for early diagnosis and access to treatment. Professionals must be made aware about the onset of HIV-related oral lesions that would be helpful to diagnose HIV or serve as indicators of a worsening condition.
\end{abstract}

Key words: AIDS-related opportunistic infections; diagnosis, oral epidemiology; developing countries

\section{Resumo}

Objetivo: Avaliar o perfil epidemiológico de portadores do HIV com manifestações estomatológicas em uma cidade sul brasileira.

Metodologia: Conduziu-se um estudo transversal, retrospectivo em 534 prontuários médicos de pacientes atendidos em 5 centros de referência.

Resultados: Cerca de $52 \%$ dos pacientes eram do gênero masculino; $88,2 \%$ eram maiores de 30 anos, 58\% foram diagnosticados no estágio avançado da doença e 78, $\%$ apresentaram rápida progressão para AIDS. A prática de hábitos nocivos foi comum (39,1\%) e 35\% estavam desempregados. Aproximadamente $60 \%$ dos sujeitos usavam terapia antirretroviral composta. A tuberculose foi a doença sistêmica mais comumente observada $(18,5 \%)$ e a candidíase bucal a manifestação estomatológica mais prevalente (50\%). Um maior risco para a ocorrência de tuberculose foi observado nos portadores de candidíase bucal e leucoplasia pilosa que faziam uso de drogas ilícitas.

Conclusão: A elevada prevalência de doenças oportunistas e a rápida progressão para AIDS suscitam maior atenção para o diagnóstico precoce e acesso ao tratamento. Os profissionais devem ser alertados sobre a ocorrência de lesões bucais associadas ao HIV, pois podem sugerir a presença de infecção pelo vírus ou indicar uma pior condição de saúde do paciente.

Palavras-chave: Infecções oportunistas relacionadas com AIDS; diagnóstico bucal; epidemiologia bucal; países em desenvolvimento

\author{
Maria Noel Marzano R. Petruzzi o \\ Fernanda Gonçalves Salum ${ }^{a}$ \\ Karen Cherubini a \\ Maria Antonia Z. de Figueiredo ${ }^{a}$
}

- Postgraduate Program in Dentistry - Oral Medicine, Pontifical Catholic University of Rio Grande do Sul, Porto Alegre, RS, Brazil
Correspondence:

Maria Antonia Zancanaro de Figueiredo

Av. Ipiranga, 6690 - Conjunto 231

Porto Alegre, RS - Brasil

90610-000

E-mail: antonia.figueiredo@pucrs.br

Received: December 27, 2011

Accepted: January 25, 2012

Conflict of Interests: The authors state that there are no financial and personal conflicts of interest that could have inappropriately influenced their work.

Copyright: (C) 2011 Petruzzi et al.; licensee EDIPUCRS. This is an Open Access article distributed under the terms of the Creative Commons AttributionNoncommercial-No Derivative Works 3.0 Unported License. 


\section{Introduction}

Since the beginning of the human immunodeficiency virus (HIV)/acquired immune deficiency syndrome (AIDS) epidemic, HIV-related oral lesions have been considered to be relevant clinical markers for diagnosis and prognosis of HIV/AIDS as they could irreversibly impair patients' health. Furthermore, due to the high morbidity indices associated with these oral pathologies, they remain a cause for hospitalization among Brazilians living with AIDS, even in the era of highly active antiretroviral therapy (HAART) $(1,2)$.

The relationship among oral pathologies, especially oral candidiasis (OC) and hairy leukoplakia (HL), immunological impairment and viral burden has been clearly shown in many reports (3). Moreover, current literature has discussed a possible association between these manifestations and the occurrence of AIDS-defining diseases, such as pneumocystosis, tuberculosis and toxoplasmosis of the brain $(2,4,5)$.

Epidemiological aspects of HIV/AIDS in different geographical areas are considered important for the identification of behavioral and co-infectious factors, as these factors are associated with the spread and widely variable clinical course of the disease (6). Therefore, the main purpose of the present study was to describe the epidemiological, clinical and laboratory characteristics of HIV carriers with HIV-associated oral lesions in a population from Porto Alegre, Rio Grande do Sul, Brazil.

\section{Methods}

In the current study, we reviewed the medical and dental charts of 534 HIV-positive adult patients ( $\geq 15$ years old). The subjects had been hospitalized or were in ambulatory accompaniment for HIV disease or related affections between 1989 and 2011. Carriers of HIV-related oral lesions were included in the study with convenience sampling.

The study methodology followed previously determined criteria for the study of the epidemiological characteristics of HIV-related oral lesions $(7,8)$ and their relationship with AIDS-defining conditions (5) that have been used for clinical staging (7). The patient's $\mathrm{CD} 4^{+}$counts and serum level of circulating HIV RNA were used to determine the degree of immunological impairment and viral status, respectively (7). Data collection included all the information from 6 months before and after the onset of oral lesions since the year of $1996(9,10)$.

Oral lesions were classified into three groups based on the recommendations of the EC Clearinghouse on Oral Problems Related to HIV Infection (11). Pathologies with doubtful diagnoses, which could not be confirmed even after the completion of auxiliary exams, were not included in the current survey. Clinical examination had been conducted by experienced physicians or dentists in accordance with the predetermined conditions of each one of the 5 referral centers where this study was developed (Oral Medicine and Medical Infectology Unit at São Lucas Hospital at Catholic Pontifical University of Rio Grande do Sul, Service of
Dental Specialties at Nossa Senhora da Conceição Hospital, Specialized Service for STD/AIDS at Vila dos Comerciários Health Center and HIV Testing and Counseling Service at Partenon Sanatorium).

Descriptive data were summarized based on conventional central tendency indexes; $95 \%$ confidence intervals (CI) were calculated for binomial distributions. Possible associations were analyzed with cross-tabulation, Chi-squared tests and a multivariate conditional logistic regression model adjusted for confounding factors. The results are shown as Odds Ratios (ORs) with 95\% CI, and statistical significance was set at $p$ value $\leq 0.05$. All analyses were performed using the Statistical Package for Social Sciences (SPSS ${ }^{\circledR}$, Chicago, IL, USA) version 18.0 software program for Windows.

The research protocol was approved by the review board of each participating institution. The survey was conducted in accordance with the Principles of Helsinki Declaration and in agreement with the Resolution $N^{\circ} 196 / 1996$ of the National Health Council of Brazil.

\section{Results}

The distribution of the demographic characteristics of the 534 patients diagnosed as HIV-positive between January 1989 and June 2011 and included in this study are presented in Table 1 . Nearly $45 \%$ of the study subjects were observed in the Infectology Unit at São Lucas Hospital, 30\% were observed at the Service of Dental Specialties at Nossa Senhora da Conceição Hospital, and the remaining $25.5 \%$ were observed at the other 3 referral centers. The patients observed at the 5 referral centers were not significantly different in gender $(P=0.328)$, age $(P=0.069)$, ethnic group $(P=0.295)$, marital status $(P=0.099)$ or occupation $(P=0.182)$.

Table 1. The demographic characteristics of HIV-infected adults with HIV-associated oral lesions. Porto Alegre, Rio Grande do Sul, Brazil, 2011 ( $\left.n^{*}=534\right)$

\begin{tabular}{|c|c|c|}
\hline Sample Characteristics & $f^{\dagger}$ & $\%$ \\
\hline $\begin{array}{l}\text { Gender } \\
\text { Male } \\
\text { Female }\end{array}$ & $\begin{array}{l}276 \\
258\end{array}$ & $\begin{array}{l}51.7 \\
48.3\end{array}$ \\
\hline $\begin{array}{l}\text { Age group (years) } \\
\quad \leq 30 \\
\quad 31-50 \\
51-70 \\
>70\end{array}$ & $\begin{array}{c}63 \\
347 \\
117 \\
7\end{array}$ & $\begin{array}{r}40.0 \\
11.8 \\
65.0 \\
21.9 \\
1.3\end{array}$ \\
\hline $\begin{array}{l}\text { Mean age } \pm \text { SD } \ddagger \text { (years) } \\
42.9 \pm 11.0\end{array}$ & & \\
\hline $\begin{array}{l}\text { Ethnic group } \\
\text { Caucasian } \\
\text { Non-Caucasian }\end{array}$ & $\begin{array}{l}363 \\
171\end{array}$ & $\begin{array}{l}68.0 \\
32.0\end{array}$ \\
\hline $\begin{array}{l}\text { Marital status } \\
\text { Single } \\
\text { Married } \\
\text { Divorced } \\
\text { Widowed }\end{array}$ & $\begin{array}{l}329 \\
129 \\
51 \\
25\end{array}$ & $\begin{array}{r}61.6 \\
24.2 \\
9.6 \\
4.7\end{array}$ \\
\hline $\begin{array}{l}\text { Occupation } \\
\text { Employed } \\
\text { Unemployed } \\
\text { Retired }\end{array}$ & $\begin{array}{c}309 \\
187 \\
38\end{array}$ & $\begin{array}{c}57.9 \\
35.0 \\
7.1\end{array}$ \\
\hline
\end{tabular}


The entire sample came from different social strata in urban areas; $80 \%$ were from Porto Alegre, and 20\% were from the metropolitan region. Among the employed patients, $171(55.3 \%)$ worked in private companies, 56 (18.1\%) were self-employed, and $22(7.1 \%)$ were public sector employees. Fifty-three (17.2\%) patients had declared themselves as housewives, and $7(2.3 \%)$ patients were prostitutes. The unemployment index was higher among men than among women in the present study $(P<0.001)$. The patient's occupation was not found to be a contributing factor for the practice of harmful habits, such as smoking $(P=0.315)$, alcohol consumption $(P=0.371)$ and illicit drug use $(P=0.377)$. In total, 164 individuals $(30.7 \%)$ were smokers, $92(17.2 \%)$ used illicit drugs, and $77(14.4 \%)$ were alcoholics.

The time elapsed between HIV diagnosis and the onset of AIDS was shorter than a year for 417 (78.1\%) patients, whereas the time for disease progression was between 1 and 5 years for $67(12.5 \%)$ subjects. Only a minority of the individuals $(9.4 \%)$ showed disease progression indicative of AIDS after 5 years. The majority of the patients were diagnosed with $4^{\text {th }}(58 \%)$ and $3^{\text {rd }}(21 \%)$ clinical stages of HIV disease based on the World Health Organization (WHO) criteria.

At the time of HIV diagnosis, from a total of 417 patients, 371 (89.1\%) individuals were carriers of an AIDSdefining systemic disease. Tuberculosis $(18.5 \%)$, oral and esophageal candidiasis $(9.7 \%)$, toxoplasmosis of the brain $(8.4 \%)$, pneumocystosis $(7.5 \%)$ and pneumonia $(6.9 \%)$ occurred frequently in this patient sample. A wide spectrum of viral, bacterial and fungal infections was described for the remaining $49 \%$ of the subjects presenting AIDS-defining conditions. Malignant neoplasms were also observed: Kaposi's sarcoma, Non-Hodgkin lymphoma and invasive cervical carcinoma were observed in 11 patients, 2 patients and 1 patient, respectively. Sexually transmitted diseases, such as syphilis, gonorrhea and genital warts, affected 22 (4.1\%) individuals at the time of HIV diagnosis. Nearly $20 \%$ of the study subjects presented an oral lesion at the time of HIV diagnosis.

OC $(50 \%)$ and HL $(9.9 \%)$, both oral lesions that are strongly associated with HIV, were highly prevalent in the study sample. Table 2 shows the prevalence of commonly occurring oral tissue lesions in the study sample. Many subjects (36.5\%) did not show any systemic disease concurrent with HIV-related affections of the bucomaxilofacial complex. However, many (38.6\%) subjects were carriers of at least one systemic disease at the time of occurrence of the oral lesions. The numbers of patients who had 2, 3, 4 and 5 systemic illnesses concurrent with oral tissue pathologies were 77 (14.4\%), 35 (6.5\%), 13 (2.4\%) and $8(1.5 \%)$, respectively.

Table 2. Prevalence of most commonly observed HIV oral lesions according to EC-Clearinghouse classification. Porto Alegre, Rio Grande do Sul, Brazil, 2011 ( $\left.n^{*}=534\right)$

\begin{tabular}{lcc}
\hline Oral Lesions & $\boldsymbol{f}^{+}$ & $\%$ \\
\hline Group I & & \\
$\quad$ Oral candidiasis & 267 & 50.0 \\
$\quad$ Hairy leukoplakia & 53 & 9.9 \\
$\quad$ Kaposi's sarcoma & 12 & 2.2 \\
$\quad$ Non-Hodgkin lymphoma & 4 & 0.7 \\
Group II & & \\
$\quad$ Herpes simplex infection & 45 & 8.4 \\
$\quad$ Atypical oral ulceration & 37 & 6.9 \\
Group III & & \\
$\quad$ Melanocytic pigmentation & 26 & 4.9 \\
$\quad$ Parotid enlargement & 10 & 1.9 \\
Others & & \\
$\quad$ Lymphadenitis of the head and \\
$\quad$ neck region
\end{tabular}

At the time of appearance of the oral lesions, 278 (52.1\%) patients had been treated with antimicrobials (antibacterials and antivirals) and $214(40.1 \%)$ had used antidepressants, vitamins, analgesics and antipyretics among other drugs. Topical and systemic antifungals had been prescribed for 172 (32.2\%) subjects, corticosteroid therapy for $55(10.3 \%)$ and tuberculostatics for $41(7.7 \%)$ patients. The majority of the subjects had used more than one medication simultaneously, including HAART (57.3\%). The mean of $\mathrm{CD}^{+}$counts and viral load (VL) levels of the subjects were $302.6( \pm 265.9)$ cells $/ \mathrm{mm}^{3}$ and $45141.2( \pm 100739.8)$ copies $/ \mathrm{mm}^{3}$.

Table 3 shows the logistic regression models used for the analysis of associations among the most prevalent oral lesions and systemic diseases. In $\mathrm{OC}(\mathrm{OR}=2.8 ; \mathrm{CI}=1.6$ to $5.2 ; P=0.001)$ and $\mathrm{HL}$ carriers $(\mathrm{OR}=2.6 ; \mathrm{CI}=1.4$ to 4.7; $P=0.002$ ), the use of illicit drugs appeared to be and additionally extrinsic factor that increased the risk for the occurrence of tuberculosis.
Table 3. Adjusted odds ratios for the association of oral candidiasis and hairy leukoplakia, and tuberculosis, toxoplasmosis of the brain and pneumocystosis. Porto Alegre, Rio Grande do Sul, Brazil, $2011\left(n^{*}=534\right)$

\begin{tabular}{lcccccc}
\hline \multirow{2}{*}{ Systemic diseases } & \multicolumn{3}{c}{ Oral candidiasis } & \multicolumn{3}{c}{ Hairy leukoplakia } \\
\cline { 2 - 7 } & $\mathrm{OR}^{\dagger}$ & $\mathrm{Cl}^{\ddagger}$ & $\boldsymbol{P}$ & $\mathrm{OR}$ & $\mathrm{Cl}$ & $\boldsymbol{P}$ \\
\hline Tuberculosis & 1.4 & 0.9 to 2.3 & 0.182 & 0.3 & 0.1 to 0.8 & 0.025 \\
Toxoplasmosis of the brain & 1.1 & 0.4 to 2.8 & 0.884 & 1.6 & 0.5 to 5.3 & 0.446 \\
Pneumocystosis & 5.2 & 0.9 to 30.0 & 0.067 & - & - & 0.999 \\
\hline
\end{tabular}

* $n$, sample size; OR+, Odds Ratio obtained in a logistic regression model adjusted by the following factors: gender, age, ethnic group, smoking, alcoholism, illicit drugs use, CD $4^{+}$counts, VL and HAART use $\mathrm{Cl}$, confidence interval; $P \leq 0.05$, statistically significant difference. 


\section{Discussion}

The most recent epidemiological bulletin of AIDS and other sexually transmitted diseases (DST) of the Brazilian Health Ministry (14) revealed that Porto Alegre is the city with the highest incidence of AIDS known cases. The cities of Canoas, Alvorada and Cachoeirinha, which are also located in the metropolitan area, were ranked among the 10 cities that presented the higher rates of incidence of the syndrome in Brazil. Different studies had demonstrated that the occurrence of HIV-associated oral lesions is common among HIV positive adults in this country $(12,13,15,16)$. These clinical manifestations would severely impair patients' condition (1) and lead to a higher demand of health assistance services.

To date, there are no reports in the literature that address the epidemiological profile of HIV positive patient carriers of oral lesions from the city of Porto Alegre and metropolitan area. Although, we considered that this subject is of great relevance to health professionals, especially the dentists. Since they should be the first professionals to diagnose and treat these oral pathologies, they intend to contribute for early diagnosis of HIV infection and detection of the disease progression.

Because we only included the carriers of HIV/AIDS with concurrent medical/dental disease, our study may have only yielded limited estimates. Although the data may not be representative of the entire HIV-positive population from Porto Alegre, they would certainly be of interest to dentists and other health professionals of this southern Brazilian region as the data were collected from 5 important referral centers involved in the management of HIV/AIDS and associated diseases.

The trend of feminization of HIV disease reported from over the world (8) was also found in this study in which a 1.1:1 male to female ratio was observed. In our sample, women were carriers of $48.3 \%$ of all oral tissue pathologies. Our results corroborate the findings of a Rio de Janeirobased study on patients with HIV-associated oral lesions that demonstrated that the number of HIV-positive women significantly increased during the period of investigation (1989 to 2004) (12). In addition, da Silva et al. (13), who evaluated HIV-oral lesions in Bahia, reported slightly more women (52.6\%) in their sample. Most of observed patients were Caucasian and single, which are consistent with the epidemiological characteristics of AIDS in Rio Grande do Sul, Brazil (14).

The mean age of the patients in this study was $42.9( \pm 11)$ years, $65 \%$ of the subjects being between 31 and 50 years of age. Similar findings were reported by Noce et al. (13), who reported that $77.7 \%$ of their patient sample was older than 30 years, and by other Brazilian authors such as Lourenço and Figueiredo (16), who reported a mean age of 38 years among patients affected by HIV-associated oral lesions from São Paulo. Most HIV carriers are of a productive age, and the occurrence of these diseases frequently hinders their work activities. A lower socioeconomic status has been considered to be a predisposing factor for higher immune suppression and for the occurrence of oral lesions among HIV-positive subjects $(13,15)$. Similarly, harmful habits reportedly occur with a higher frequency among socially vulnerable persons (16), thus putting them at risk of developing or acquiring other health disorders.

It was not possible to identify a relationship between unemployment and abuse of noxious substances $(P=0.315)$ among the patients in this study. However, we found an association between the use of illicit drugs and the occurrence of tuberculosis in carriers of $\mathrm{OC}(\mathrm{OR}=2.8 ; \mathrm{CI}=1.6$ to 5.2; $P=0.001)$ and $\mathrm{HL}(\mathrm{OR}=2.6 ; \mathrm{CI}=1.4$ to $4.7 ; P=0.002)$. Previous reports have described the greater susceptibility of persistent users of crack cocaine of death from AIDSrelated causes due to the greater occurrence of opportunistic infections (17). The hypothesis that the use of crack cocaine contributes for cessation of HAART and independently accelerates the rates of disease progression (18) has also been discussed in current literature. The respiratory damage caused by crack cocaine may predispose its users to tuberculosis infectivity (19), especially if there is some existing degree of immune injury. For reasons not known to the investigators, 100 patients in our study sample were noncompliant to the proposed antiretroviral treatment, which possibly contributed to the deterioration of their health.

Although nearly $60 \%$ of the study sample had access to HAART and the majority of the patients received proper medical care for prophylaxis and treatment of AIDS-related diseases, the prevalence of secondary systemic diseases remained high. As observed in other studies $(1,2,4-6)$, opportunistic illnesses, such as tuberculosis, pneumocystosis and toxoplasmosis of the brain, were frequently observed in our study sample. The findings of this study revealed that most of the 534 subjects presented an AIDS-defining pathology at the time of diagnosis and that nearly $60 \%$ were at the $4^{\text {th }}$ WHO classification stage of the disease (7). These results thus strengthen the hypothesis that delayed medical identification of HIV leads to rapid disease progression and the development of AIDS.

The late diagnosis may reflect the low index of voluntary HIV-testing in the Brazilian population (20) or it may represent the lack of patients' self-perception or negligence of the early signs and symptoms of HIV, such as fever, weight loss, diarrhea, persistent lymphadenitis and OC (4). Thus, the delay between the time of HIV infection and its diagnosis postpones the entry of the affected individual into medical care and negatively correlates with the patient's health status (21).

Although many patients presented concurrent systemic disease with oral lesions, no significant relationship was found between the appearance of OC and HL and the onset of the systemic diseases, which was in contrast to the findings of previous reports $(5,22)$. Both OC and HL have been proposed as clinical indicators for the initiation of prophylactic co-trimoxazole therapy for pneumocystosis and toxoplasmosis (22). Although the risk of developing pneumocystosis was found to be 5 -fold greater for patients 
with OC than for those without OC in our sample, this finding was not statistically significant $(\mathrm{OR}=5.2 ; \mathrm{CI}=0.9$ to $30.0 ; P=0.067)$, probably because of the small sample size and the large number of adjustment factors.

It is noteworthy that $\mathrm{OC}$ was present in nearly $10 \%$ of the patients at the time of diagnosis, which reaffirms the relevance of this lesion as a consistent sign for early detection of HIV infection. Furthermore, despite the lack of statistical significance, the high risk of developing pneumocystosis concurrently with OC indicates that OC may serve as a useful clinical indicator of disease progression. While it may not be justifiable to monitor HIV based on its clinical features alone if adequate laboratory facilities are available, it is worth deliberating whether $\mathrm{OC}$ is a reliable marker of a worsening systemic condition in patients in resourceconstrained areas.

Though OC was prevalent in $50 \%$ of the patients the frequency at which different clinical presentations of OC occurred had not been noted in the charts. Although we believe that the clinical characteristics are relevant, it is still a matter of debate as to whether pseudomembranous or erythematous OC can indicate disease progression, viral burden or HAART failure $(3,14)$.

The frequency of HIV-associated oral lesions observed in this study was consistent with the findings of other preliminary studies $(3,13)$. Although we could not predict changes in the prevalence of oral lesions in our study sample due to the cross-sectional design of the study, we did find the prevalence of KS to be low compared to data from epidemiological studies on oral lesions in the HAART era. Of the $12 \mathrm{KS}$ cases observed in our sample, 6 (50\%) patients had never been treated with antiretroviral therapy, $2(16.7 \%)$ patients had stopped HAART and 4 (33.3\%) patients were on HAART. Thus, it was not clear whether the prevalence of KS was a result of therapeutic failure, the duration of treatment or the kind of drugs used in the therapy. However, other studies have shown that KS, as well as HL, melanocytic pigmentation and parotid gland enlargement (PGE) were more persistent and had a slower response to HAART (23).

In the current survey, the occurrence of PGE was observed in $10(1.9 \%)$ patients, who were treated with HAART. This disorder is not a commonly reported finding among AIDS patients but its occurrence has increased over time $(10,24)$. The appearance of PGE was previously correlated with improved prognosis (24) and considered to be a sign of immune reconstitution syndrome (IRIS) in Brazilian patients under HAART (25). This lesion has been reported to cause xerostomia and taste disturbance, impairing patients' quality of life (10). Hence, although the effects of HAART on oral lesions are beginning to become known, longitudinal studies are necessary to confirm the value of PGE as a marker of better prognosis or as the onset of IRIS.

Of 534 patients, $103(19.3 \%)$ presented oral lesions at the time of HIV diagnosis and the remaining 431 (80.7\%) developed these manifestations during the course of HIV/ AIDS, even while receiving HAART. This finding highlights the importance of oral examination as a complementary diagnostic resource for the early identification and monitoring of HIV infection and the importance of established diagnostic criteria so that most of these lesions can be diagnosed with the help of their clinical features and with a high degree of reliability $(6,9)$.

\section{Conclusions}

The epidemiological, clinical and laboratory features observed in this survey reinforce the need for regional strategies for the prevention, early diagnosis and treatment of HIV/AIDS and related co-morbidities. Most patients in this study were diagnosed at an advanced stage of HIV disease. They presented low $\mathrm{CD} 4^{+}$counts, high viral loads and elevated prevalence of oral lesions and AIDS-defining diseases, even after beginning HAART. The high prevalence of HIV associated oral lesions identified in the patient sample, at the time of HIV diagnosis, should be halted. Dentists and other health professionals might be aware to the occurrence of these affections, since they would be auxiliary signs for the diagnosis of HIV or indicate the progression to AIDS.

\section{Acknowledgments}

The authors thank the teams of Medical Infectology Unit at São Lucas Hospital, the Service of Dental Specialties at Nossa Senhora da Conceição Hospital, the Vila dos Comerciários Health Center and the HIV Testing and Counselling Service at Partenon Sanatory, in particular, Dr. Ana Lúcia Didonet Moro, Dr. Willian Penafiel, Dr. Maurício Volkweis and Dr. Patrícia Forte.

\section{Authorship and Contributorship}

Maria Noel Marzano Rodrigues Petruzzi, Fernanda Gonçalves Salum, Karen Cherubini and Maria Antonia Zancanaro de Figueiredo contributed to the conception and design of the study; the acquisition, analysis and interpretation of the data and the drafting and review of the article. 
1. Nobre V, Braga E, Rayes A, Serufo JC, Godoy P, Nunes N et al. Infecções oportunistas em pacientes com AIDS internados em um hospital universitário do sudeste do Brasil. Rev Inst Med Trop Sao Paulo 2003;45:67-74.

2. Ravetti CG, Pedroso ER. Study on the clinical and epidemiological characteristics of patients with human immunodeficiency virus at the walk-in service of the teaching hospital of the Federal University of Minas Gerais. Rev Inst Med Trop Sao Paulo 2009;42:1 14-8.

3. Gaurav S, Keerthilatha PM, Archna N. Prevalence of oral manifestations and their association with CD4/CD8 ratio and HIV viral load in South India. Int J Dent 2011 [cited 2011 dec 01]; 201 1:964278. Available at: http://www.hindawi.com/journals/ijd/2011/964278/

4. Tamí-Maury IM, Willig JH, Jolly PE, Vermund S, Aban I, Hill JD et al. Prevalence, incidence, and recurrence of oral lesions among HIV-infected patients on HAART in Alabama: a twoyear longitudinal study. South Med J 2011;104:561-6.

5. Anteyi KO, Thacher TD, Yohanna S, Idoko JI. Oral manifestations of HIV-AIDS in Nigerian patients. Int J STD AIDS 2003;14:395-8.

6. Nittayananta W, Chanowanna N, Winn T, Silpapojakul K, Rodklai A, Jaruratanasirikul S et al. Co-existence between oral lesions and opportunistic systemic diseases among HIVinfected subjects in Thailand. J Oral Pathol Med 2002;31:163-68.

7. Melnik SL, Nowjack-Raimer R, Kleinman DV, Swango PA. A guide for epidemiological studies of oral manifestations of HIV infection. Geneva: WHO; 1993 [cited 2011 dec 01]. Available at: http://whqlibdoc.who.int/publications/1993/9241544538.pdf

8. World Health Organization. Antiretroviral therapy for HIV infection in adults and adolescents: recommendations for a public health approach. Geneva: WHO; 2010 [cited $2011 \mathrm{dec} 01$ ] Revision. Available at: http://www.who.int/hiv/pub/guidelines/artadultguidelines.pdf

9. Ramírez-Amador V, Anaya-Saavedra G, Calva JJ, Clemades-Pérez-de-Corcho T, LópezMartínez $\mathrm{C}$ et al. HIV-related oral lesions, demographic factors, clinical staging and antiretroviral use. Arch Med Res 2006;37:646-54.

10. Carpio E, López V, Fardales V, Benítez I. Oral manifestations of HIV infection in adult patients from the province of Sancti Spiritus, Cuba. J Oral Pathol Med 2009;38:126-31.

11. Classification and diagnosis criteria for oral lesion in HIV infection. EC-Clearinghouse on Oral Problems Related to HIV Infection and WHO Collaborating Center on Oral Manifestations of The Immunodeficiency Virus. J Oral Pathol Med 1993;22:289-91 .

12. Ferreira S, Noce C, Júnior AS, Gonçalves L, Torres S, Meeks V et al. Prevalence of oral manifestations of HIV infection in Rio de Janeiro, Brazil from 1988 to 2004. AIDS Patient Care STDS 2007;21:724-31.

13. da Silva CA, Dourado I, Dahia SR, Harzheim E, Rutherford GW. Oral manifestations of HIV infection in patients receiving highly active antiretroviral therapy (HAART) in Bahia, Brazil. J Public Health Dent 2008;68:178-81.

14. Brasil. Ministério da Saúde. Programa Nacional de Doenças Sexualmente Transmissíveis/ AIDS. Bol Epidemiol DST/AIDS 2011 [cited $2011 \mathrm{dec}$ 10];8(1):1-26. Available at: http://www.aids.gov.br/sites/default/files/anexos/publicacao/2011/50652/vers_o_ preliminar_69324.pdf

15. Noce CW, Ferreira SM, Silva Júnior A, Dias EP. Association between socioeconomic status and HIV-associated oral lesions in Rio de Janeiro from 1997 to 2004. Braz Oral Res 2009;23:149-54.

16. Lourenço AG, Figueiredo LT. Oral lesions in HIV infected individuals from Ribeirão Preto, Brazil. Med Oral Patol Oral Cir Bucal 2008 [cited 2011 dec 01];13:E281-6. Available at: http://www.medicinaoral.com/medoralfree01/v13i5/medoralv13i5p281.pdf

17. Gasparin AB, Ferreira FV, Danesi CC, Mendoza-Sassi RA, Silveira J, Martinez AM et al. Prevalence of oral lesions in persons with HIV and associated factors in a southern Brazilian city. Cad Saude Publica 2009;25:1307-15.

18. Rossi D, Radulich G, Muzzio E, Naveira J, Sosa-Estani S, Rey J et al. Multiple infections and associated risk factors among non-injecting cocaine users in Argentina. Cad Saude Publica 2008;24:965-74.

19. Cook JA, Burke-Miller JK, Cohen MH, Cook RL, Vlahov D, Wilson TE et al. Crack cocaine, disease progression, and mortality in a multicenter cohort of HIV-1 positive women. AIDS 2008;22:1355-63.

20. Baum MK, Rafie C, Lai S, Sales S, Page B, Campa A. Crack-cocaine use accelerates HIV disease progression in a cohort of HIV-positive drug users. J Acquir Immune Defic Syndr 2009;50:93-9.

21. Story A, Bothamley G, Hayward A. Crack cocaine and infectious tuberculosis. Emerg Infect Dis 2008;14:1466-9.

22. Sá MS, Sampaio J, Haguihara T, Ventin FO, Brites C. Clinical and laboratory profile of HIVpositive patients at the moment of diagnosis in Bahia, Brazil. Braz J Infect Dis 2007;1 1:395-8.

23. Carnicer-Pont D, Vives N, Casabona I Barbarà J. Epidemiology of human immunodeficiency virus infection: delay in diagnosis. Enferm Infecc Microbiol Clin 201 1;29:144-51.

24. Tripathi A, Gardner LI, Ogbuanu I, Youmans E, Stephens T, Gibson JJ et al. Predictors of time to enter medical care after a new HIV diagnosis: a statewide population-based study. AIDS Care $2011 ; 23: 1366-73$.

25. Ortega KL, Ceballos-Salobreña A, Gaitán-Cepeda LA, Magalhães MG. Oral manifestations after immune reconstitution in HIV patients on HAART. Int J STD AIDS 2008; 19(5): 305-8. 